\title{
Effects of expression of human or bovine growth hormone genes on sperm production and male reproductive performance in four lines of transgenic mice
}

\author{
A. Bartke ${ }^{1}$, E. M. Naar ${ }^{1}$, L. Johnson ${ }^{2}$, M. R. May ${ }^{2}$, M. Cecim ${ }^{1}$, J. S. Yun ${ }^{3}$ \\ and T. E. Wagner ${ }^{3}$ \\ ${ }^{1}$ Department of Physiology, School of Medicine, Southern Illinois University, Carbondale, \\ IL 62901, USA; ${ }^{2}$ Department of Veterinary Anatomy, Texas A \& M University, College Station, \\ TX 77843, USA; and ${ }^{3}$ Edison Animal Biotechnology Center, Ohio University, Athens, \\ OH 45701, USA
}

\begin{abstract}
Summary. Reproductive performance was studied in transgenic males from lines expressing and transmitting four hybrid genes: mouse metallothionein-I/human growth hormone $(\mathrm{GH})(M T / h G H), M T / h G H$ placental variant $(M T / h G H \cdot V), \mathrm{MT} /$ bovine $\mathrm{GH}$ $(M T / b G H)$ and phosphoenolpyruvate carboxykinase/bGH $(P E P C K / b G H)$. Each male was exposed to three normal females for 1 week and to three different normal females for another week. Females were examined for vaginal plugs and necropsied on day 14 of pregnancy. Males were killed for analysis of organ weights, numbers of testicular spermatids, numbers of epididymal sperm and measurements of plasma glucose concentration. Fertility of $M T / h G H$ and $M T / h G H \cdot V$ transgenic males was significantly lower than in normal males, primarily because most males failed to impregnate any females. In females that became pregnant, the numbers of corpora lutea, total fetuses and live fetuses did not differ from those in females mated to normal (nontransgenic) males. Fetal crown-rump length on day 14 of pregnancy did not differ between litters sired by normal or by transgenic males. Weights of testes and seminal vesicles were significantly greater in all four types of transgenic male, but daily sperm production per unit weight $\left(\mathrm{g}^{-1}\right)$ of testis was not affected and epididymal sperm reserves were either normal or slightly higher than normal. Plasma glucose concentrations were significantly higher in $P E P C K / b G H$ mice than in other mice. Average or individual reproductive performance of transgenic males from the various lines did not correlate with any of the parameters examined except for significantly heavier seminal vesicles in $M T / h G H$ and $M T / h G H \cdot V$ males than in normal males; these transgenic males exhibited a high incidence of infertility. Since $h G H$ and $h G H \cdot V$, but not $b G H$, are lactogenic in rodents, it was concluded that chronic stimulation of $\mathrm{GH}$ and prolactin receptors by ectopically produced human GHs in transgenic mice compromises male fertility by an unknown mechanism. Reduced fertility of transgenic males with $M T / h G H$ or $M T / h G H \cdot V$ hybrid genes is due to failure to inseminate or impregnate females rather than to reduced numbers of spermatozoa or gross changes in the male reproductive system.
\end{abstract}

Keywords: growth hormone; transgenic mice; spermatogenesis; fertility

\section{Introduction}

Growth hormone $(\mathrm{GH})$ can promote testicular growth and function in animals with inherited or experimentally induced GH deficiency (Bartke, 1965; Zipf et al., 1978) and appears to play a role in 
male puberty (Handelsman et al., 1987; Al-Haboby et al., 1988). However, high concentrations of $\mathrm{GH}$ in acromegalic patients and in transgenic boars is associated with reduced libido (Jadresic $e t$ al., 1982; Pinkert et al., 1991) and there is evidence for suppression of testicular development and function in transgenic boars and rams expressing heterologous GH genes (Pinkert et al., 1991; Rexroad, 1991). Expression of various GH genes in transgenic mice is often associated with greatly reduced reproductive performance (Hammer et al., 1984; Yun \& Wagner, 1987; Bartke et al., 1988). However, transgenic male mice that express experimentally introduced $\mathrm{GH}$ genes and exhibit phenotypic consequences of high $\mathrm{GH}$, but are fertile and transmit the heterologous gene to their progeny, have been produced in several laboratories (Hammer et al., 1984; McGrane et al., 1988; Selden et al., 1988, 1989). Indeed, most, if not all, currently available established lines of $\mathrm{GH}$-expressing transgenic mice are routinely maintained by crossing transgenic males with normal females.

In the course of studies of the hypothalamic-pituitary-gonadal axis in four lines of transgenic mice expressing human or bovine GH genes (Bartke et al., 1988, 1990; Steger et al., 1991), we noticed a high incidence of male sterility in one of the lines and loss of fertility at an abnormally early age in this and in two other lines. We therefore decided to obtain quantitative evaluation of sperm production and male reproductive performance in these animals. The characteristics of the lines examined in terms of their origin, developmental stages at the onset of hybrid-gene expression and plasma concentrations of heterologous $\mathrm{GH}$, as well as differences between the actions of human (h)GH and bovine (b)GH in mice were discussed previously (Bartke et al., 1988, 1990, 1991; Naar et al., 1991; Steger et al., 1991).

\title{
Materials and Methods
}

\begin{abstract}
Animals
We examined transgenic male mice with the following gene constructs: (i) mouse metallothionein-I/human $\mathrm{GH}(M T / h G H)$; (ii) $\mathrm{MT} /$ human placental $\mathrm{GH}^{\prime} \mathrm{B}^{\prime}$ variant $(M T / h G H \cdot V)$; (iii) $\mathrm{MT} /$ bovine $\mathrm{GH}(M T / b G H)$; and (iv) phosphoenolpyruvate carboxykinase/bGH $(P E P C K / b G H)$.

The production and initial characterization of these lines with respect to, for example, somatic growth, sites of transgene expression and female reproductive functions have been described previously (McGrane et al., 1988; Selden et al., 1988, 1989; Mayerhofer et al., 1990; Naar et al., 1991). The animals used for the present study were produced by crossing transgenic males with $\mathrm{C} 57 \mathrm{BL} / 6 \times \mathrm{C} 3 \mathrm{H} \mathrm{F}$, hybrid females purchased from the Jackson Laboratory (Bar Harbor, ME, USA). The animals were housed in a room with controlled photoperiod (12 h light:12 h dark) and temperature $\left(22 \pm 2^{\circ} \mathrm{C}\right.$ ) with constant access to a laboratory rodent pelleted diet (Teklad 6\% Rat/Mouse Diet 002 , Harlan Sprague-Dawley, Madison, WI, USA; $24 \%$ protein, $6 \%$ fat) and tap water. Young mice were weaned at the age of 21-24 days and housed in all-male groups (five animals per cage) until used for the experiments. The main phenotypic, reproductive and pathological characteristics of transgenic animals in the four lines examined are summarized in Table 1.

Twenty-seven transgenic males ranging in age from 19 to 25 weeks and representing the four lines and seven of their normal (nontransgenic) siblings were each placed in a cage containing three normal, young adult, virgin ICR females (purchased from Harlan Sprague--Dawley, Indianapolis, IN, USA). The females were checked daily for vaginal plugs. One week later, the males were mated to three different ICR females, which were checked daily for vaginal plugs. On day 14 of pregnancy, the females were killed and examined for numbers of corpora lutea and live and dead fetuses.
\end{abstract}

\section{Organs and sperm production}

Three-and-a-half weeks after the start of this experiment, the males were killed by decapitation. Trunk blood was collected for measurements of glucose (Sigma kit: Sigma, St Louis, MO, USA), the testes and epididymides were removed and immediately frozen for subsequent determination of numbers of testicular spermatids, daily sperm production, numbers of epididymal spermatozoa and transit time. The weights of various reproductive and nonreproductive organs were recorded, because this information has not been reported before for most of the lines used. In an attempt to distinguish between hypertrophy and hyperplasia, the contents of protein and DNA in the liver, heart and kidney were determined using procedures described by Bradford (1976) and Burton (1956), respectively. 
Table 1. Phenotypic, reproductive and pathological characteristics of four lines of transgenic mice expressing various growth hormone $(G H)$ genes in comparison with normal mice*

\begin{tabular}{|c|c|c|c|c|}
\hline Genes: & $M T / h G H$ & $M T / h G H \cdot V$ & $M T / b G H$ & $P E P C K / b G H$ \\
\hline Postweaning growth & Accelerated & Accelerated & Accelerated & Accelerated \\
\hline Adult body weight & Increased & Increased & Increased & Increased \\
\hline $\begin{array}{l}\text { Heterologous } \mathrm{GH} \text { in } \\
\text { plasma (ng ml-1) }\end{array}$ & $5-15$ & - & $8-25$ & $150-500$ \\
\hline $\begin{array}{l}\text { Concentration of insulin- } \\
\text { like growth factor-I in } \\
\text { plasma }\end{array}$ & High & High & High & High \\
\hline Male fertility $\dagger$ & Fertile & Some fertile & Fertile & Fertile \\
\hline Reproductive life span $\dagger$ & Reduced & Reduced & $\begin{array}{l}\text { Approximately } \\
\text { normal }\end{array}$ & Reduced \\
\hline Female fertility $\dagger$ & Sterile & Fertile & Fertile & Some fertile \\
\hline $\begin{array}{l}\text { Gross pathological } \\
\text { findings }\end{array}$ & \multicolumn{2}{|c|}{$\begin{array}{l}\text { Age-related hypertrophy of male } \\
\text { accessory reproductive glands } \\
\text { Early onset and high incidence of } \\
\text { mammary tumours in females } \\
\text { (earlier in } M T / h G H)\end{array}$} & $\begin{array}{l}\text { None } \\
\text { s }\end{array}$ & $\begin{array}{l}\text { Weight loss, loss of fat stores } \\
\text { and general debilitation } \\
\text { followed by death at } 8-12 \\
\text { months }\end{array}$ \\
\hline
\end{tabular}

*Includes previously reported data (Yun \& Wagner, 1987; Bartke et al., 1988; McGrane et al., 1988; Selden et al., 1988, 1989; Cecim, 1990; Cecim et al., 1990; Mayerhofer et al., 1990; Bartke et al., 1991; Naar et al., 1991; Steger et al., 1991 and authors' unpublished observations).

†Based on observations in the course of maintenance of our breeding colony of these lines.

Daily sperm production and numbers of epididymal spermatozoa were determined in another group of $16 M T / h G H$ transgenic males and 15 nontransgenic siblings of these animals. All these animals were 10-14 weeks old, had never been used for breeding and were group-housed until they were killed.

For counting the spermatids, the frozen testes were thawed, weighed, decapsulated and homogenized for $2 \mathrm{~min}$ in a Waring blender in $100 \mathrm{ml}$ of fluid containing $150 \mathrm{mmol} \mathrm{NaCl} l^{-1}, 0.03 \% \mathrm{v} / \mathrm{v}$ Triton X-100, and $3.8 \mathrm{mmol} \mathrm{NaN}_{3} 1^{-1}$ in water (Amann \& Lambiase, 1969). Homogenization-resistant spermatids were counted by phase-contrast cytometry as described by Amann et al. (1976) and Johnson \& Neaves (1983). On the basis of their morphology and chromatic condensation, spermatids that survive homogenization correspond to maturation-phase spermatids (steps 14 16) that occur in stages II-VIII in mice (Oakberg, 1956a, b). Since these stages have a total duration of 4.84 days of a cycle of 8.63 days, the daily sperm production per testis was calculated by dividing the number of maturation-phase spermatids in the homogenates by the estimated lifespan of these spermatids (4.84 days). The number of spermatozoa in the epididymis was determined in epididymal homogenates prepared as described for the testis (Johnson \& Varner, 1988). Epididymal transit time was determined by dividing the number of sperm in the epididymis by daily sperm production of the ipsilateral testis from the same animal (Amann et al., 1976; Johnson \& Varner, 1988).

\section{Statistical analysis}

Statistical significance of the differences was evaluated using $\chi$ square analysis for percentages, $t$ test for comparison of two means and analysis of variance followed by Duncan's multiple range test for comparison of more than two means.

\section{Results}

During 2 weeks of cohabitation with females, each of seven control (nontransgenic), six of seven $M T / b G H$ and six of seven $P E P C K / b G H$ males sired at least one litter (Table 2). In contrast, only two of seven $M T / h G H \cdot V$ males and two of six $M T / h G H$ males proved to be fertile $(P<0.05$ versus nontransgenic controls). The proportion of females that became pregnant after cohabiting for one week with a fertile male was significantly lower than normal in matings with transgenic $M T / h G H$ males (Table 2). Among females mated to $M T / h G H \cdot V$ transgenic males, the proportion of females 
that had a vaginal plug and became pregnant was also significantly lower $(P<0.01)$. The net effect of these differences was a significantly lower proportion of females becoming pregnant after cohabiting for one week with a transgenic $M T / h G H, M T / h G H \cdot V$ or $P E P C K / b G H$ male (Table 2), but the proportion becoming pregnant after cohabiting with a $M T / b G H$ transgenic male was not affected.

Table 2. Fertility of transgenic male mice expressing various gene constructs

\begin{tabular}{|c|c|c|c|c|c|}
\hline $\begin{array}{l}\text { Genes: } \\
n:\end{array}$ & $\begin{array}{l}\text { Normal } \\
7\end{array}$ & $\begin{array}{c}M T / h G H \\
6\end{array}$ & $\begin{array}{c}M T / h G H \cdot V \\
7\end{array}$ & $\begin{array}{c}M T / b G H \\
7\end{array}$ & $\underset{7}{P E P C K / b G H}$ \\
\hline Percentage of males fertile & 100 & $33 \cdot 3^{\mathrm{a}}$ & $28 \cdot 6^{\mathrm{a}}$ & $85 \cdot 7$ & 85.7 \\
\hline $\begin{array}{l}\text { Percentage of females pregnant per } \\
\text { fertile male }\end{array}$ & $52 \cdot 3$ & $16 \cdot 6^{\mathrm{a}}$ & $25 \cdot 0$ & $66 \cdot 7$ & 44.5 \\
\hline Percentage of females pregnant & 54.8 & $5 \cdot 6^{\mathrm{b}}$ & $7 \cdot 0^{\mathrm{b}}$ & $57 \cdot 1$ & $38 \cdot 1^{\mathrm{a}}$ \\
\hline Mean number of corpora lutea & $13.8 \pm 0.7$ & $17^{\mathrm{c}}$ & $12 \cdot 5 \pm 0 \cdot 5$ & $13.6 \pm 0.7$ & $13.6 \pm 0.9$ \\
\hline Mean number of fetuses & $13 \cdot 4 \pm 0 \cdot 5$ & $14^{\mathrm{c}}$ & $14 \cdot 5 \pm 0.5$ & $12 \cdot 7 \pm 0 \cdot 7$ & $13 \cdot 7 \pm 0 \cdot 8$ \\
\hline Mean number of live fetuses & $13 \cdot 3 \pm 0 \cdot 6$ & $13^{\mathrm{c}}$ & $14 \cdot 0 \pm 0 \cdot 0$ & $12 \cdot 4 \pm 0 \cdot 6$ & $13 \cdot 1 \pm 0 \cdot 8$ \\
\hline
\end{tabular}

${ }^{a}$ Different from normal controls, $P<0.05$.

${ }^{b}$ Different from normal controls, $P<0.001$.

"Only one female was autopsied.

Data are means \pm SEM.

Examination of females on day 14 of pregnancy revealed no differences between those mated to various transgenic or normal males in terms of the numbers of corpora lutea, or total and live fetuses or proportion of corpora lutea represented by fetuses (Table 2).

Body weight of transgenic males was significantly greater than normal in every line, as expected (Table 3). Analysis of autopsy data revealed that testicular weight did not increase in proportion to body weight. Thus, although the absolute weight of the testis was greater in transgenic males from every line examined, the relative weight of the testis was either unaltered ( $M T / h G H$ and $M T / b G H)$ or significantly lower $(M T / h G H \cdot V$ and $P E P C K / b G H)$. Absolute weight of the seminal vesicles was greater in each type of transgenic male examined, but the relative weight of the seminal vesicles was significantly greater only in males expressing human GH genes ( $h G H$ or $h G H \cdot V$ ). The absolute weight of the liver was much higher in all transgenic males and the relative weight of the liver was significantly greater, except for the $M T / h G H$ males. Both the absolute and the relative weights of the spleen were greater in $M T / h G H \cdot V$ and $P E P C K / b G H$ transgenic males than in normal males. Absolute weights of the adrenals and the heart were significantly greater in each of the four types of transgenic males. The apparent increases in the absolute weights of the thymus and the kidney were significant in only some of the lines, apparently as a result of greater variance of these measures. The relative weights of the thymus, the adrenals, the heart and the kidney did not differ between the normal and transgenic males (data not shown). There were no differences between normal and transgenic males in the concentration of DNA in the liver (data not shown). Protein concentration ( $\mu \mathrm{g}$ protein $\mathrm{mg}^{-1}$ wet weight) was significantly lower in the livers of $P E P C K / b G H$ males and not altered in males from the remaining three lines (Table 3 ). There were no differences between the normal and the transgenic males (from any of the four lines examined) in the protein concentration in the kidney and the heart, or in protein:DNA ratios in the liver, kidney and heart (data not shown).

Plasma glucose concentration was significantly greater in $P E P C K / b G H$ males than in normal males and appeared to be similarly altered in $M T / b G H$ males (Table 3), but, in transgenic males expressing human $\mathrm{GH}$ genes, it was similar to that measured in nontransgenic controls.

Daily sperm production per testis was significantly greater in $M T / h G H, M T / b G H$ and $P E P C K / b G H$ males (Table 4) than in normal males, but daily sperm production $\mathrm{g}^{-1}$ of testicular parenchyma did not differ between normal and transgenic mice. The epididymal content of 
Table 3. Body and organ weights, hepatic protein concentration and plasma glucose in transgenic male mice expressing various gene constructs

\begin{tabular}{|c|c|c|c|c|c|}
\hline $\begin{array}{l}\text { Genes: } \\
n:\end{array}$ & $\begin{array}{c}\text { Normal } \\
7\end{array}$ & $\begin{array}{c}M T / h G H \\
6\end{array}$ & $\begin{array}{c}M T / h G H \cdot V \\
7\end{array}$ & $\begin{array}{c}M T / b G H \\
7\end{array}$ & $\begin{array}{c}P E P C K / b G H \\
7\end{array}$ \\
\hline Body wt (g) & $37 \cdot 6 \pm 4 \cdot 4^{\mathrm{a}}$ & $56 \cdot 5 \pm 2 \cdot 3^{b}$ & $55 \cdot 6 \pm 2 \cdot 3^{b}$ & $53 \cdot 2 \pm 1 \cdot 6^{\mathrm{b}}$ & $59 \cdot 9 \pm 1 \cdot 4^{b}$ \\
\hline $\begin{array}{l}\text { Testes wt } \\
\text { Absolute (mg) } \\
\text { Relative }\end{array}$ & $\begin{array}{l}218 \pm 10^{\mathrm{a}} \\
622 \pm 62^{\mathrm{a}}\end{array}$ & $\begin{array}{l}326 \pm 11^{\mathrm{c}} \\
581 \pm 22^{\mathrm{a}}\end{array}$ & $\begin{array}{l}254 \pm 15^{\mathrm{b}} \\
458 \pm 22^{\mathrm{c}}\end{array}$ & $\begin{array}{l}276 \pm 11^{\mathrm{b}} \\
519 \pm 15^{\mathrm{a}, \mathrm{b}, \mathrm{c}}\end{array}$ & $\begin{array}{l}279 \pm 10^{b} \\
469 \pm 23^{b}\end{array}$ \\
\hline $\begin{array}{l}\text { Seminal vesicle wt } \\
\text { Absolute }(\mathrm{mg}) \\
\text { Relative }\end{array}$ & $\begin{aligned} 260 & \pm 15^{a} \\
73 & \pm 6^{a}\end{aligned}$ & $\begin{array}{l}620 \pm 90^{\mathrm{b}} \\
108 \pm 10^{\mathrm{b}}\end{array}$ & $\begin{array}{l}597 \pm 47^{b} \\
107 \pm 7^{b}\end{array}$ & $\begin{array}{l}529 \pm 46^{\mathrm{b}} \\
100 \pm 10^{\mathrm{a}, \mathrm{b}}\end{array}$ & $\begin{array}{l}600 \pm 74^{\mathrm{b}} \\
100 \pm 13^{\mathrm{a}, \mathrm{b}}\end{array}$ \\
\hline $\begin{array}{l}\text { Liver wt } \\
\text { Absolute (g) } \\
\text { Relative }\end{array}$ & $\begin{array}{l}1.60 \pm 0.05^{\mathrm{a}} \\
4.53 \pm 0.34^{\mathrm{a}}\end{array}$ & $\begin{array}{l}3 \cdot 08 \pm 0.27^{b} \\
5 \cdot 45 \pm 0.39^{a}\end{array}$ & $\begin{array}{l}4.05 \pm 0.30^{\mathrm{c}} \\
7.27 \pm 0.40^{\mathrm{b}}\end{array}$ & $\begin{array}{l}3 \cdot 56 \pm 0.27^{\mathrm{b}, \mathrm{c}} \\
6 \cdot 70 \pm 0.53^{\mathrm{b}}\end{array}$ & $\begin{array}{l}4 \cdot 28 \pm 0.30^{\mathrm{c}} \\
7 \cdot 10 \pm 0.41^{\mathrm{b}}\end{array}$ \\
\hline Liver protein $\left(\mu \mathrm{g} \mathrm{mg}^{-1}\right)$ & $20 \cdot 2 \pm 0 \cdot 9^{\mathrm{a}}$ & $17 \cdot 6 \pm 1 \cdot 4^{a, b}$ & $19 \cdot 6 \pm 1 \cdot 3^{a}$ & $19 \cdot 9 \pm 0 \cdot 9^{a}$ & $16 \cdot 0 \pm 0.9^{b}$ \\
\hline $\begin{array}{l}\text { Spleen wt } \\
\text { Absolute (mg) } \\
\text { Relative }\end{array}$ & $\begin{array}{c}95 \pm 9^{a} \\
271 \pm 37^{a}\end{array}$ & $\begin{array}{l}147 \pm 6^{a} \\
264 \pm 18^{a}\end{array}$ & $\begin{array}{l}274 \pm 4^{b} \\
491 \pm 79^{b}\end{array}$ & $\begin{array}{l}159 \pm 16^{\mathrm{a}} \\
293 \pm 27^{\mathrm{a}}\end{array}$ & $\begin{array}{l}301 \pm 20^{\mathrm{b}} \\
504 \pm 37^{\mathrm{b}}\end{array}$ \\
\hline Thymus wt (mg)* & $29 \pm 5^{\mathrm{a}}$ & $53 \pm 10^{\mathrm{a}, \mathrm{b}}$ & $48 \pm 12^{\mathrm{a}, \mathrm{b}}$ & $54 \pm 5^{b}$ & $40 \pm 4^{\mathrm{a} \cdot \mathrm{b}}$ \\
\hline Adrenal gland wt (mg)* & $1 \cdot 80 \pm 0.24^{\mathrm{a}}$ & $3.90 \pm 0.26^{b}$ & $3.23 \pm 0.39^{b}$ & $3.46 \pm 0.31^{b}$ & $3.09 \pm 0.23^{b}$ \\
\hline Heart wt (mg)* & $155 \pm 8^{\mathrm{a}}$ & $259 \pm 5^{b}$ & $295 \pm 26^{\mathrm{b}, \mathrm{c}}$ & $271 \pm 14^{\mathrm{b}, \mathrm{c}}$ & $312 \pm 13^{\mathrm{c}}$ \\
\hline Kidney wt (mg)* & $643 \pm 154^{a}$ & $741 \pm 56^{\mathrm{a}, \mathrm{b}}$ & $995 \pm 65^{b, c}$ & $764 \pm 44^{\mathrm{a}, \mathrm{b}}$ & $1078 \pm 53^{c}$ \\
\hline Plasma glucose $\left(\mathrm{mg} \mathrm{dl}^{-1}\right)$ & $123 \pm 5^{a \cdot b}$ & $120 \pm 4^{b}$ & $126 \pm 9^{\mathrm{a}, \mathrm{b}}$ & $147 \pm 12^{\mathrm{a}, \mathrm{c}}$ & $150 \pm 4^{c}$ \\
\hline
\end{tabular}

Values given are means \pm SEM; details in the text.

*No significant differences in relative weights.

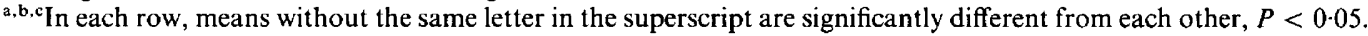

spermatozoa appeared to be greater in transgenic males of each type, but only in $P E P C K / b G H$ males was this difference statistically significant. There were no significant differences in epididymal transit time between normal and transgenic males.

Table 4. Daily sperm production, number of epididymal spermatozoa and epididymal transit time in transgenic male mice expressing various gene constructs

\begin{tabular}{|c|c|c|c|c|c|}
\hline $\begin{array}{l}\text { Genes: } \\
n:\end{array}$ & $\begin{array}{l}\text { Normal } \\
7\end{array}$ & $\begin{array}{c}M T / h G H \\
6\end{array}$ & $\begin{array}{c}M T / h G H \cdot V \\
7\end{array}$ & $\begin{array}{c}M T / b G H \\
7\end{array}$ & $\begin{array}{c}P E P C K / b G H \\
7\end{array}$ \\
\hline $\begin{array}{r}\text { Weight of testicular } \\
\text { parenchyma (mg) }\end{array}$ & $96 \pm 4^{a}$ & $145 \pm 6^{c}$ & $108 \pm 6^{a, b}$ & $118 \pm 5^{b}$ & $121 \pm 5^{b}$ \\
\hline $\begin{array}{l}\text { Daily sperm production } \\
\left(\times 10^{-6}\right) \\
\text { per testis } \\
\mathrm{g}^{-1}\end{array}$ & $\begin{array}{l}4 \cdot 18 \pm 0 \cdot 45^{\mathrm{a}, \mathrm{b}} \\
43 \cdot 1 \pm 2 \cdot 9^{\mathrm{a}}\end{array}$ & $\begin{array}{l}5 \cdot 42 \pm 0 \cdot 26^{\mathrm{c}} \\
37 \cdot 7 \pm 2 \cdot 0^{\mathrm{a}}\end{array}$ & $\begin{array}{l}3 \cdot 97 \pm 0 \cdot 32^{\mathrm{a}} \\
36 \cdot 9 \pm 2 \cdot 4^{\mathrm{a}}\end{array}$ & $\begin{array}{l}5 \cdot 23 \pm 0 \cdot 25^{\mathbf{b}, \mathbf{c}} \\
44 \cdot 6 \pm 2 \cdot 6^{\mathrm{a}}\end{array}$ & $\begin{array}{l}5 \cdot 15 \pm 0 \cdot 40^{\mathrm{b} . \mathrm{c}} \\
42 \cdot 9 \pm 2 \cdot 8^{\mathrm{a}}\end{array}$ \\
\hline $\begin{array}{l}\text { Epididymal spermatozoa } \\
\qquad\left(\times 10^{-6}\right)\end{array}$ & $28 \cdot 3 \pm 2 \cdot 0^{\mathrm{a}}$ & $33 \cdot 4 \pm 2 \cdot 5^{\mathbf{a}, \mathrm{b}}$ & $30 \cdot 5 \pm 1.9^{\mathrm{a}}$ & $33 \cdot 7 \pm 3 \cdot 1^{a, b}$ & $39 \cdot 3 \pm 1 \cdot 8^{b}$ \\
\hline Transit time (days) & $7 \cdot 0 \pm 0.39^{\mathrm{a}}$ & $6 \cdot 22 \pm 0.48^{a}$ & $7.81 \pm 0.46^{a}$ & $6.83 \pm 0.57^{\mathrm{a}}$ & $7.65 \pm 0.98^{\mathrm{a}}$ \\
\hline
\end{tabular}

a.b.c In each row, values without the same letter in the superscript are significantly different; $P<0.05$.

Data are means \pm SEM. 
When daily sperm production and epididymal sperm reserves were examined in a larger number of transgenic $M T / h G H$ and normal (nontransgenic) males, the results were similar. Thus, sperm production per testis was significantly greater, but sperm production $\mathrm{g}^{-1}$ of testis was not altered, in transgenic males (Table 5). However, epididymal content of spermatozoa was significantly greater in this group of younger transgenic animals, which had not been used for breeding.

Table 5. Weights of testes and epididymes and daily sperm production and number of epididymal spermatozoa in 10-14-weekold transgenic $M T / h G H$ male mice and in their normal littermates

\begin{tabular}{lccc}
\hline & Normal & $M T / h G H$ & $P$ \\
\hline$n$ & 15 & 16 & - \\
Testis wt $(\mathrm{mg})$ & $103 \pm 3.9$ & $138 \pm 5.3$ & $<0.01$ \\
$\quad \begin{array}{l}\text { Parenchyma } \\
\quad \text { Tunica }\end{array}$ & $95 \pm 3.9$ & $126 \pm 4.8$ & $<0.01$ \\
Daily sperm production $\left(\times 10^{-6}\right)$ & $7.7 \pm 0.4$ & $12.2 \pm 0.8$ & $<0.01$ \\
$\quad$ per testis g & & & \\
& $2.95 \pm 0.14$ & $3.58 \pm 0.21$ & $<0.05$ \\
Epididymal wt $(\mathrm{mg})$ & $31.4 \pm 1.6$ & $28.5 \pm 1.5$ & $\mathrm{NS}$ \\
Epididymal sperm $\left(\times 10^{-6}\right)$ & $31.5 \pm 0.9$ & $37.2 \pm 1.1$ & $<0.01$ \\
\hline
\end{tabular}

Data are means \pm SEM.

\section{Discussion}

Results of this study indicate that reproductive functions are significantly compromised in transgenic male mice expressing human GH genes. During two consecutive 1-week periods of cohabitation of three females with each male, $<10 \%$ of females exposed to $M T / h G H$ or $M T / h G H \cdot V$ transgenic males, and $>50 \%$ of females exposed to nontransgenic control males became pregnant. Indeed, most transgenic $M T / h G H$ and $M T / h G H \cdot V$ males failed to sire a single litter under the conditions of this experiment. Observations during breeding lines of transgenic mice indicated that most $M T /$ $h G H$ males will eventually sire litters if they are housed with females for long periods, while at least $50 \%$ of $M T / h G H \cdot V$ males cannot breed.

In contrast, breeding performance of transgenic males expressing the bGH gene with either MT or PEPCK promoter did not differ from the performance of their normal (nontransgenic) siblings except for a modest, but statistically significant, reduction in the proportion of females that became pregnant after I week of exposure to $P E P C K / b G H$ males. These data are fully consistent with the observations made in the course of maintaining these lines and two other lines of $P E P C K / b G H$ mice with different numbers of transgene copies.

The reasons for reduced fertility of $M T / h G H$ and $M T / h G H \cdot V$ transgenic males are not readily apparent from quantitative assessment of spermatogenesis or from the analysis of autopsy data. The only characteristic that appeared to distinguish transgenic mice expressing $h G H$ genes from those expressing the $b G H$ gene was a greater proportional increase in the weight of the seminal vesicles in the former. Increased weight of the seminal vesicles and the coagulating glands in adult transgenic $M T / h G H$ and $M T / h G H \cdot V$ males is associated with massive hypertrophy of these organs later in life (Cecim et al., 1990) and is thought to be due to lactogenic activity of hGH and hGH.V molecules in mice (Forsyth et al., 1965; Bartke et al., 1990; Nickel et al., 1990). However, it is not obvious how excessive stimulation of the growth and secretory activity of male accessory reproductive glands would compromise fertility, particularly in animals studied several months before the onset of gross enlargement of these organs. 
Comparisons of organ weights, daily sperm production and epididymal sperm content between males that did and those that did not sire litters within each line did not reveal any significant differences or consistent trends.

Thus, reasons for reduced reproductive performance of $M T / h G H$ and $M T / h G H \cdot V$ males remain to be elucidated. Secondary sterility of $12-15$-month-old $M T-h G H$ males appears to be due to difficulties in gaining intromission and inability to inseminate females without loss of libido, as assessed from mount latencies (Bartke et al., 1991). However, our preliminary studies did not reveal differences in mount latency, intromission latency or other measures of copulatory behaviour between fertile and sterile $M T / h G H \cdot V$ transgenic males tested with ovariectomized females brought into behavioural oestrus by injections of oestradiol and progesterone (A. Bartke and D. Mayerhofer, unpublished observations).

In females examined 14 days after mating with transgenic males, no abnormalities were apparent in mortality before or after implantation or in the number of fetuses. Examination of other normal females mated to transgenic males from the same lines (Naar et al., 1991) revealed no differences in fetal growth (weight and crown-rump length), placental weight, or concentrations of plasma progesterone or insulin-like growth factor-I compared with values in females mated to normal siblings of transgenic males. These findings suggest that quantitatively normal sperm production per unit of testicular weight and normal, or slightly higher, numbers of spermatozoa per testis and per epididymis in transgenic mice are associated with absence of gross deficiencies in sperm quality.

It is difficult to relate reproductive performance of transgenic males to information on their endocrine status. Although various abnormalities were detected in the metabolism of hypothalamic neurotransmitters and in the regulation of release of luteinizing hormone and prolactin (Bartke $e t$ al., 1988, 1990; Chandrashekar et al., 1988; Steger et al., 1990, 1991) as well as in the control of testicular LH receptors (Amador et al., 1990), transgenic males are not androgen deficient. This conclusion is based on measurements of plasma testosterone concentration and testosterone production in vitro under basal conditions and after stimulation with human chorionic gonadotrophin (Chandrashekar et al., 1988; Amador et al., 1990; A. Bartke, A. Lingle \& D. Schultz, unpublished observations) and is consistent with data on the weight of androgen-dependent organs.

Nonomura et al. (1985) reported low fertility in C57BL/6 males with long-term (16 weeks) experimentally induced hyperprolactinaemia. In the present study, low fertility was noted in males producing human growth hormones that are lactogenic in mice (Forsyth et al., 1965; Selden et al., 1988; Bartke et al., 1990) and not in those expressing bGH genes. Berger et al. (1989) reported reductions in absolute testis weight and in fertility in one of two lines of mice selected for high adult body weight as a result of high growth after weaning, but no information is available on the possible endocrine correlates of these findings.

Low fertility in transgenic mice should probably not be considered as premature reproductive ageing. Fertility in the various lines did not correlate with lifespan (Table 1), and data from our breeding colony indicated that a high incidence of male infertility in $M T / h G H \cdot V$ males was evident at the age of 2-3 months. The low reproductive performance of transgenic males may have been due to insertional mutagenesis.

In the lines of transgenic $M T / h G H, M T / h G H \cdot V, M T / b G H$ and $P E P C K / b G H$ mice examined in the present study, male reproductive performance did not correlate with reproductive performance of transgenic females from the same lines (Naar et al., 1991). Presumably, reproductive abnormalities in both sexes are due to different mechanisms.

Differences in body and organ weights between transgenic and normal mice in the present study were generally consistent with the previously described consequences of ectopic expression of various $G H$ genes in mice with MT and PEPCK promoters (Hammer et al., 1984; Shea et al., 1987; Cecim, 1990) and particularly with the results of analysis of growth allometry in $M T / r G H$ and $M T / b G H$ mice (Shea et al., 1987; Cecim, 1990). Thus, adult body weight of transgenic animals was approximately $50 \%$ greater than normal in each of the lines. Differences between normal and 
transgenic mice in weights of organs such as heart, kidney, thymus and adrenal gland were proportional to differences in body weight. Differences in the weights of the liver and spleen in some of the lines were greater and the weights of the testis were generally less than in proportion to the difference in adult body weight. These results agree with the previous report of growthpromoting activity of the $h G H \cdot V$ gene in the same line of transgenic mice (Selden et al., 1988) and with the suggestion that expression of different $G H$ genes leads to comparable phenotypic effects in transgenic mice, even if circulating concentrations of heterologous $\mathrm{GH}$ are very different (e.g. $M T / b G H$ vs. $P E P C K / b G H$ ) (Matthews et al., 1988). Lack of differences between transgenic and normal males in the protein:DNA ratios in the liver, heart and kidney suggests that the size of these organs in transgenic mice was increased primarily by hyperplasia. Normal concentration of protein in these organs, with the exception of livers in $P E P C K / b G H$ males, tends to support this conclusion. However, the effects of transgene expression on endomitosis or incidence of polyploidy have not been evaluated. Low protein concentration in the livers of transgenic PEPCK/bGH males probably reflects greater lipid content in the livers of these animals. This conclusion is supported by gross observations of liver histology in transgenic animals of this strain (M. Cecim, unpublished observations).

High concentration of glucose in plasma of $P E P C K / b G H$ males that have very high concentrations of circulating $\mathrm{GH}$ is consistent with the well-documented 'diabetogenic' action of this hormone (Daughaday, 1985), although McGrane et al. (1990) did not detect altered serum glucose concentration in $P E P C K / b G H$ transgenic mice.

In the lines of transgenic mice examined in the present study, expression of human $G H$ genes was associated with significant reduction in fertility, whereas expression of the $b G H$ gene was compatible with normal reproductive performance. Reduced fertility of $M T / h G H$ and $M T / h G H \cdot V$ transgenic males was not associated with any defects in numbers of testicular or epididymal sperm or with gross abnormalities of the male reproductive system and was due mainly to significantly reduced ability to inseminate females during a standardized period of exposure. In females impregnated by these males, fertilization rate, embryo survival and fetal growth appeared to be normal, at least during the first 2 weeks of pregnancy. Thus, ectopic production of hormones that bind to GH and prolactin receptors in transgenic mice interferes with male fertility via mechanisms that remain to be elucidated. In contrast, chronic excess of bGH, which is 'purely' somatotrophic in rodents, has little, if any, effect on male reproductive performance.

This work was supported by the Cooperative State Research Service, US Department of Agriculture, under agreement No. 89-37240-4584 and by NIH grant HD20001. We thank J. Weis, S. McGee and T. Began for assistance in this study and M. Hilt for typing the manuscript.

\section{References}

Al-Haboby, A.H., Loseth, K.J., Wheaton, J.E. \& Crabo, B.G. (1988) Neonatal hemiorchidectomy of bulis alters plasma growth hormone levels and advances onset of pubertal testosterone secretion. Domestic Animal Endocrinology 5, 61-69.

Amador, A.G., Mayerhofer, A., Bartke, A., Wagner, T.E. \& Yun, J.S. (1990) Testicular function in mouse lines with different bovine growth hormone (GH) transgenes. In Program of the 72nd Annual Meeting of the Endocrine Society, Abstract 422. Williams \& Wilkins, Baltimore, MD, USA.

Amann, R.P. \& Lambiase, J.T., Jr (1969) The male rabbit. III. Determination of daily sperm production by means of testicular homogenates. Journal of Animal Science 28, 309-374.
Amann, R.P., Johnson, L., Thompson, D.L., Jr \& Pickett, B.W. (1976) Daily spermatozoal production, epididymal spermatozoal reserves and transit time of spermatozoa through the epididymis of the rhesus monkey. Biology of Reproduction 15, 586-592.

Bartke, A. (1965) The response of two types of dwarf mice to growth hormone, thyrotropin, and thyroxine. General and Comparative Endocrinology 5, 418-426.

Bartke, A., Steger, R.W., Hodges, S.L., Parkening, T.A., Collins, T.J., Yun, J.S. \& Wagner, T.E. (1988) Infertility in transgenic female mice with human growth hormone expression: evidence for luteal failure. Journal of Experimental Zoology 248, 212-214.

Bartke, A., Steger, R.W., Parkening, T.A., Collins, T.J., Yun, J.S. \& Wagner, T.E. (1990) Influence of human 
and bovine growth hormones on the regulation of prolactin release in transgenic mice. In Neuroendocrinology: New Frontiers, pp. 39-48. Eds D. Gupta, H. A. Wollman \& M. B. Ranke. Brain Research Promotion, Tübingen, Germany.

Bartke, A., Shire, J.G.M., Chandrashekar, V., Steger, R.W., Mayerhofer, A., Amador, A.G., Bain, P., Tang, K., Yun, J.S. \& Wagner, T.E. (1991) Effects of human growth hormone on reproductive and neuroendocrine functions in transgenic mice. In Transgenic Animals, pp. 237-248, Eds N. L. First \& F. P. Haseltine. Butterworth-Heinemann, Boston, MA, USA.

Berger, T., Calvert, C.C. \& Bradford, G.E. (1989) Reduced male reproductive capacity in mice with high genetic potential for post-weaning growth. Journal of Reproduction and Fertility 87, 33-38.

Bradford, M.M. (1976) A rapid and sensitive method for the quantification of microgram quantities of protein utilizing the principle of protein-dye binding. Analytical Biochemistry 72, 248-254.

Burton, K. (1956) A study of the conditions and mechanism of the diphenylamine reaction for the colorimetric estimation of deoxyribonucleic acid. Biochemical Journal 62, 315-322.

Cecim, M. (1990) Growth allometry of skin, carcass and organs in mice transgenic for bovine growth hormone. In Program of the 72nd Annual Meeting of the Endocrine Society, Abstract 910. Williams \& Wilkins, Baltimore, MD, USA.

Cecim, M., Bartke, A. \& Shire, J. (1990) Seminal vesicle (SV) hypertrophy and reduced life span in transgenic mice with human or bovine growth hormone $(\mathrm{GH})$ gene expression. Journal of Andrology 11, 30-P (abst 37).

Chandrashekar, V., Bartke, A. \& Wagner, T.E. (1988) Endogenous human growth hormone (GH) modulates the effects of gonadotropin-releasing hormone on pituitary function and the gonadotropin response to the negative feedback effect of testosterone in adult male transgenic mice bearing $\mathrm{hGH}$ gene. Endocrinology 123, 2717-2722.

Daughaday, W.H. (1985) The anterior pituitary. In Williams' Textbook of Endocrinology, 7th edn, pp. 568-613. Eds J. D. Wilson \& D. W. Foster. W. B. Saunders Co., Philadelphia, PA, USA.

Forsyth, I.A., Folley, S.J. \& Chadwick, A. (1965) Lactogenic and pigeon crop-stimulating activities of human pituitary growth hormone preparations. Journal of Endocrinology 31, 115-126.

Hammer, R.E., Palmiter, R.D. \& Brinster, R.L. (1984) Partial correction of murine hereditary growth disorder by germ-line incorporation of a new gene. Nature 311, 65-67.

Handelsman, D.J., Spalviero, J.A., Scott, C.D. \& Baxter, R.C. (1987) Hormonal regulation of the peripubertal surge of insulin-like growth factor-I in the rat. Endocrinology 120, 491-496.

Jadresic, A., Banks, L.M., Child, D.F., Diamant, L., Doyle, F.H., Fraser, T.R. \& Joplin, G.F. (1982) The acromegaly syndrome. Quarterly Journal of Medicine 202, 189-204.

Johnson, L. \& Neaves, W.B. (1983) Enhanced daily sperm production in the remaining testis of aged rats following hemicastration. Journal of Andrology 4, 162-166.
Johnson, L. \& Varner, D.D. (1988) Effect of daily spermatozoan production but not age on transit time of spermatozoa through the human epididymis. Biology of Reproduction 39, 812-817.

McGrane, M.M., de Vente, J., Yun, J., Bloom, J., Park, E., Wynshaw, A., Wagner, T., Rottman, F.M. \& Hanson, R.W. (1988) Tissue-specific expression and dietary regulation of a chimeric phosphoenolpyruvate carboxykinase/bovine growth hormone gene in transgenic mice. Journal of Biological Chemistry 263, $11443-11451$.

McGrane, M.M., Yun, J.S., Moorman, A.F.M., Lamers, W.H., Hendrick, G.K., Arafah, B.M., Park, E.A., Wagner, T.E. \& Hanson, R.W. (1990) Metabolic effects of developmental, tissue and cell specific expression of a chimeric phosphoenolpyruvate carboxykinase (GTP)/bovine growth hormone gene in transgenic mice. Journal of Biological Chemistry 265, 22 371-22 379.

Matthews, L.S., Hammer, R.E., Brinster, R.L. \& Palmiter, R.D. (1988) Expression of insulin-like growth factor I in transgenic mice with elevated levels of growth hormone is correlated with growth. Endocrinology 123, 433-437.

Mayerhofer, A., Weis, J., Bartke, A., Yun, J.S. \& Wagner, T.E. (1990) Effects of transgenes for human and bovine growth hormones on age-related changes in ovarian morphology in mice. Anatomical Record 227, 175-186.

Naar, E.M., Bartke, A., Majumdar, S.S., Buonomo, F.C., Yun, J.S. \& Wagner, T.E. (1991) Fertility of transgenic female mice expressing bovine growth hormone (GH) or human growth hormone variant genes. Biology of Reproduction 45, 178-187.

Nickel, B.E., Kardami, E. \& Cattini, P.A. (1990) The human placental growth hormone variant is mitogenic for rat lymphoma $\mathrm{Nb} 2$ cells. Endocrinology 126, 971-976.

Nonomura, M., Hoshino, K., Harigaya, T., Hashimoto, $H$. \& Yoshida, O. (1985) Effects of hyperprolactinaemia on reproduction in male mice. Journal of Endocrinology 107, 71-76.

Oakberg, E.F. (1956a) A description of spermiogenesis in the mouse and its use in analysis of the cycle of the seminiferous epithelium and germ cell renewal. American Journal of Anatomy 99, 391-413.

Oakberg, E.F. (1956b) Duration of spermatogenesis in the mouse and timing of stages of the cycle of seminiferous epithelium. American Journal of Anatomy 99, 507-516.

Pinkert, C.A., Kooyman, D.L. \& Dyer, T.J. (1991) Enhanced growth performance in transgenic swine. In Transgenic Animals, pp. 251-258. Eds N. L. First \& F. P. Haseltine. Butterworth-Heinemann, Boston, MA, USA.

Rexroad, C.E., Jr (1991) Production of sheep transgenic for growth hormone genes. In Transgenic Animals, pp. 259-263. Eds N. L. First \& F. P. Haseltine. Butterworth-Heinemann, Boston, MA, USA.

Selden, R.F., Wagner, T.E., Blethen, S., Yun, J.S., Rowe, M.E. \& Goodman, H.M. (1988) Expression of the human growth hormone variant in cultured fibroblasts and transgenic mice. Proceedings of National Academy of Sciences of the USA 85, 82418245 .

Downloaded from Bioscientifica.com at 04/26/2023 11:47:58AM via free access 
Selden, R.F., Yun, J.S., Moore, D.D., Rowe, M.E., Malia, M.A., Wagner, T.E. \& Goodman, H.M. (1989) Glucocorticoid regulation of human growth hormone expression in transgenic mice and transiently transfected cells. Journal of Endocrinology 122, 4960 .

Shea, B.T., Hammer, R.E. \& Brinster, R.L. (1987) Growth allometry of the organs in giant transgenic mice. Endocrinology 121, 1924-1930.

Steger, R.W., Bartke, A., Parkening, T.A., Collins, T., Yun, J.S. \& Wagner, T.E. (1990) Neuroendocrine function in transgenic male mice with human growth hormone expression. Neuroendocrinology 52, 106-111.
Steger, R.W., Bartke, A., Parkening, T.A., Collins, T. Buonomo, F.C., Tang, K., Wagner, T.E. \& Yun, J.S. (1991) Effects of heterologous growth hormones on hypothalamic and pituitary function in transgenic mice. Neuroendocrinology 53, 365-372.

Yun, J.S. \& Wagner, T.E. (1987) Study of human growth hormone transgenic mice: female reproductive system. In Program of the 10th Korea Symposium on Science and Technology, Seoul, Korea 3(1), 279-282.

Zipf, W.B., Payne, A.H. \& Kelch, R.P. (1978) Prolactin, growth hormone, and luteinizing hormone in the maintenance of testicular luteinizing hormone receptors. Endocrinology 103, 595-600.

Received 6 February 1991 